\title{
(2) \\ Applications of the Columbus steerable guidewire
}

\section{OPEN ACCESS}

\author{
Alexander von Hessling, Tomás Reyes del Castillo (D) , Lutz Lehmann, \\ Justus Erasmus Roos, Grzegorz Karwacki
}

- Additional supplemental material is published online only. To view, please visit the journal online (http://dx.doi. org/10.1136/neurintsurg2021-018120).

Radiology and Nuclear Medicine, Luzerner Kantonsspital Zentrumsspital, Luzern, Switzerland

Correspondence to Dr Tomás Reyes del

Castillo, Radiology and Nuclear Medicine, Luzerner Kantonsspital Zentrumsspital, Luzern 6000, Switzerland: tomas.reyesdelcastillo@luks.ch

Received 11 August 2021 Accepted 8 November 2021

\section{ABSTRACT}

The Columbus steerable guidewire (Rapid Medical, Israel) is a 0.014 inch guidewire with a remotely controlled deflectable tip intended for neuronavigational purposes. ${ }^{1}$ The tip can be shaped by pulling or pushing the handle. Pulling the handle decreases the radius (from 4 $\mathrm{mm}$ to $2 \mathrm{~mm}$ ) and curves the tip, while pushing the handle increases the curvature radius and straightens the tip until it bends in the opposite direction. The amount of deflection is at the discretion of the operator. Video 1 The response of the Columbus guidewire to rotational movements is inferior to that of standard wires, and the tip is very soft and malleable but brings great support when bent. We present two cases where the Columbus guidewire was used. In the first case, the Columbus enabled us to probe a posterior cerebral artery arising from a giant basilar tip aneurysm without wall contact. In the second case, the Columbus was used as a secondary wire to help cannulate the pericallosal artery in a patient with a recurrent anterior complex aneurysm; this subsequently permitted successful stent-assisted coiling of the aneurysm.

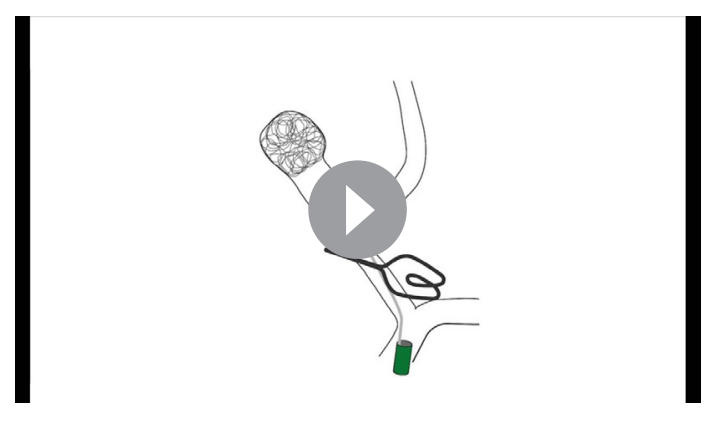

Video 1

Twitter Tomás Reyes del Castillo @tomrdc

Acknowledgements We thank Rapid Medical for the support provided during this study.
Contributors AvH was the main author of the manuscript.

TRdC was a major contributor in filming the video and writing the manuscript. LL contributed with the animation and edition of the video. JER and GK provided administrative support and a critical review of the intellectual content of the video. All authors read and approved the final manuscript.

Funding The authors have not declared a specific grant for this research from any funding agency in the public, commercial or not-for-profit sectors.

Competing interests None declared.

Patient consent for publication Consent obtained directly from patient(s).

Ethics approval All procedures performed in studies involving human participants were in accordance with the ethical standards of the institutional and/or national research committee and with the 1964 Helsinki declaration and its later amendments or comparable ethical standards. Informed consent was obtained from all individual participants included in the study. This study was approved by the EKNZ (Ethikkomission Nordwest und Zentralschweiz) with the project ID: 2021-00276.

Provenance and peer review Not commissioned; externally peer reviewed.

Supplemental material This content has been supplied by the author(s). It has not been vetted by BMJ Publishing Group Limited (BMJ) and may not have been peer-reviewed. Any opinions or recommendations discussed are solely those of the author(s) and are not endorsed by BMJ. BMJ disclaims all liability and responsibility arising from any reliance placed on the content. Where the content includes any translated material, BMJ does not warrant the accuracy and reliability of the translations (including but not limited to local regulations, clinical guidelines, terminology, drug names and drug dosages), and is not responsible for any error and/ or omissions arising from translation and adaptation or otherwise.

Open access This is an open access article distributed in accordance with the Creative Commons Attribution Non Commercial (CC BY-NC 4.0) license, which permits others to distribute, remix, adapt, build upon this work non-commercially, and license their derivative works on different terms, provided the original work is properly cited, appropriate credit is given, any changes made indicated, and the use is non-commercial. See: http:// creativecommons.org/licenses/by-nc/4.0/.

ORCID iD

Tomás Reyes del Castillo http://orcid.org/0000-0002-3080-1568

Reyes del Castillo

J Neurolntervent Surg Epub ahead of print: [please include Day Month Year]. doi:10.1136/

neurintsurg-2021-018120 